\title{
2 源クラスターからの複合・コアシェルクラスター集合体作製
}

\author{
隅山 兼治, 加藤 亮二, 日原岳彦, 彭 棟梁 \\ 名古屋工業大学大学院ながれ領域物質工学尃攻, 干 466-8555 名古屋市昭和区御器所町.
}

\section{Composite and Core-Shell Cluster assemblies Prepared with Two Cluster Sources}

\author{
Kenji Sumiyama, Ryoji Katoh, Takehiko Hihara and Dong-Liang Peng \\ Department of Materials Science and Engineering, Nagare-College, Nagoya Institute of Technology, Nagoya 466-8555.
}

Received May 7, 2004

\begin{abstract}
SYNOPSIS
A plasma-gas condensation cluster deposition system with two sources has been applied for preparing $\mathrm{Co} / \mathrm{Si}$ clusters assemblies. When a separation plate is inserted between two glow-discharge-rooms, a mixture of $\mathrm{Co}$ and $\mathrm{Si}$ clusters is obtained: small Co clusters are distributed at random, while the Si clusters are aggregated to form large secondary particles. Without a separation plate, on the other hand, core-shell clusters are obtained: a Co core is covered by small $\mathrm{Si}$ crystallites. The magnetization measurement at $5 \mathrm{~K}$ shows that the magnetic coercive force of $\mathrm{Co} / \mathrm{Si}$ cluster assemblies is much smaller than that of $\mathrm{Co}$ cluster assemblies. Since the $\mathrm{Si}$ shell prevents Co cluster surfaces from their oxidation, such core-shell clusters will be used as building blocks for novel nano-structurecontrolled materials.
\end{abstract}

KEY WORDS

plasma-gas-condensation, core-shell cluster, transmission electron microscopy, magnetic property

\section{1 緒言}

近年，ナノサイス微粒子の構造，組織，集合状態を制御す ることにより，材料の高性能・複合機能化，集積度向上が図 られている1 ${ }^{1}$ このような微粒子の研究は, 上田等の実験と久 保等の理論が先駆けとなり2),広範かつ系統的な応用研究を経 で, プリント配線や高機能性ペースト等への実用化が急速に 進んでいる4).

我々のグループでは, より小さいクラスターに着目し", 生 成効率，汎用性の高いプラスマガス中凝縮クラスター堆積装 置の開発と,7,クラスターサイスの単分散化を行ってきた ${ }^{7,8)}$. 透過電子顕微鏡と質量分析計を用いたクラスター形成過程の 観測に基づき，単分散サイスのクラスター合成には，気化原 子からクラスター核が生成する空間，時間を限定し，その後 は，気化原子をクラスター核に凝集させ，真空度の高い空間 に引き出してクラスター同士の衝突を抑制しながら基板上に 堆積させることが重要であることを明らかにした ${ }^{8-109}$.

よく知られているように, クラスターは通常の蒸着の際の 気化原子と同梯に，基板表面を抬散していく5.11). クラスター の基板上での集合過程については，幾何学的，電気的，磁気
的な連結・ネットワークがマクロなクラスター堆積領域全体 に行き渡るパーコレーション現象として把握することができ， その閾值か識別される ${ }^{12,13)}$. また, 基板上でクラスター同士の ランダムな付着が進行してできるクラスター集合体は, 多孔 質体である ${ }^{5,14)}$.ところが, プラズマガス中凝縮法で生成した クラスターは数十\%がイオン化されているのでの, 高電圧の バイアス基板上に入射させると強制着陸させることができる゙9. このようなクラスター集合体は, 高密度な膜となり, 強度や 磁気的性質も向上する ${ }^{19}$. 基板の温度を高めることによって も, クラスターの表面㹡散が促進されるが, 同時にクラス タ一同士の合体・融合が生じ易くなるため, クラスターの初 期サイスを維持できないわ。

次に,クラスター集合直前にその表面を酸化させることが, クラスターの安定化に有効であることを提示した.このよう な酸化膜で覆われたコアシェルクラスターは酸化の進行が抑 制されるばかりでなく，様々な機能か付与される.例えば, Co のクラスター表面をCoOで被覆したコアシェルクラスター集

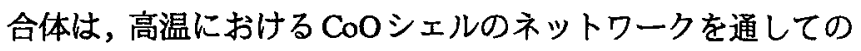
半導体的な電気伝導から低温における金属Coコア間のトンネ 
ル型のクーロンブロッケード電気伝導へと遷移し，低温で大 きな磁気抵抗効果を示す ${ }^{18)}$.また，強磁性Coコアと反強磁性 $\mathrm{CoO}$ シェルの間に強い磁気交換相互作用が働き，一方向異方 性ならびにランダム磁気異方性が誘起されるとともに界，磁化 の緩和現象において，高温の熱活性型から低温のトンネル型 緩和へと遷移する ${ }^{20}$. クラスターのコアサイスやシェルの厚さ が均一であるので，これら 2 種類の逻移が極めて明瞭に観測 される.更に，金属材料学の伝統に従い，合金クラスターを 作製すると,機能を向上させることが期待される。例えば,Co やFeクラスターは $10 \mathrm{~nm}$ 以下になると, 単磁区粒子となるが, 室温でも熱摇らきが大きく，超常磁性を示す ${ }^{13)}$. しかし，CoPt や FePtなどの規則合金クラスターにおいては，磁気異方性 が顕著となり $5 \mathrm{~nm}$ 程度でも室温での強磁性が安定化される ${ }^{21)}$.

この考え方を更に発展させ，異種クラスターを同時に発生 させ，その堆積過程を制御することにより，更なる機能の向 上か期待される。本稿では，この目的のために試作した 2 源 クラスター発生・堆積装置, それにより作製したCoとSiクラ スターの堆積例とその磁気的性質について概観する.

\section{2 源クラスター生成・堆積装置}

Fig.1は，2源ブラスママ・ガス中凝縮クラスター発生・堆積 装置の概略図である22).2つの原料を気化蒸発させるためのス

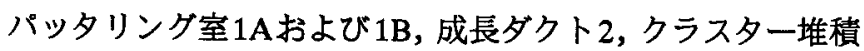
室3で構成される. スパッタリング室 $1 \mathrm{~A}, 1 \mathrm{~B}$ とクラスタ堆積 室は成長ダクト 2 のスルを通して空間的に船がっている。 スパッタリング室 $1 \mathrm{~A}$ と1Bの間には取り外し可能な仕切り板 が挿入可能であり，それそれれの室で発生した蒸気や形成され たクラスターがスパッタリング室で混合するのを防ぐことが できる、Arガスは，原材料の気化，気化した原料原子の冷却 (Ar原子と衝突して運動エネルギーを失う), 原料原子の凝縮・ 核生成・成長(気化原子同士が衝突して2原子分子あるいはそ れより大きい分子やクラスターへと成長する際に発生する㠜 集エネルギーの脱離)に奇与するばかりでなく、スパッタリン グ領域から金属蒸気を引き出し, Ar気流とともに生成したク

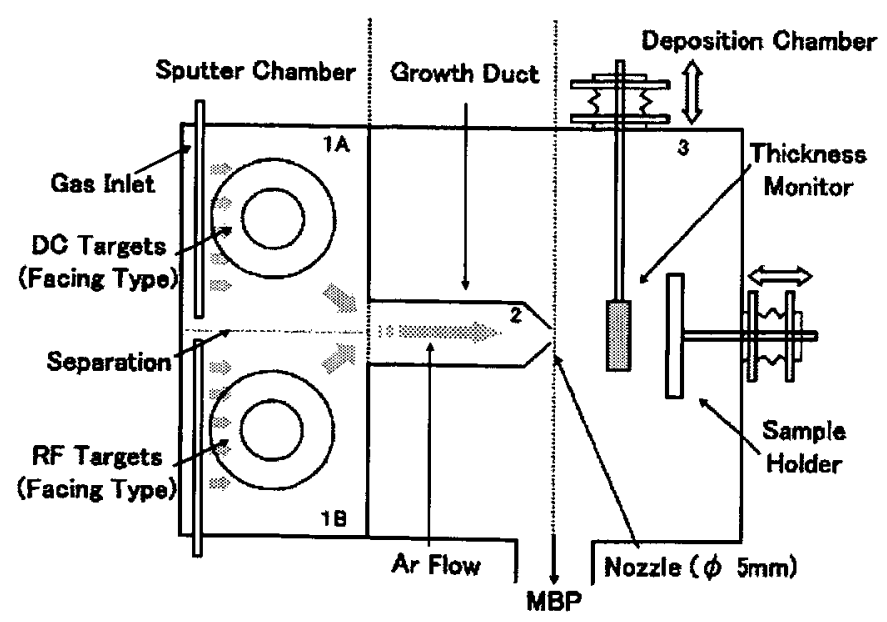

Fig.1 A double source plasma-gas-condensation system ${ }^{22)}$.
ラスターを成長ダクトを通して婎積室へ搬送する役目を担っ ている.クラスター堆積量は基板の直前の位置に挿入可能な 水晶振動子膜厚計により見積もることができる. 放電用 $\mathrm{Ar} の$ 分圧 $P_{\mathrm{A}}$ は 300-600 Pa 程度と, 通常のスパッタリング成膜の 時の $P_{\mathrm{Ar}}=0.1-1 \mathrm{~Pa}$ と比べて 2 桁以上高いので. ア一ク放電を 抑制することが大きな課題となる.Fig.1の装置において，ス パッタリング室 $1 \mathrm{~A}$ は先に開発された装置 ${ }^{6-8)}$ と同様 DCモ一 ドでプラスマをを発生させており，金属原料の気化・蒸発を行

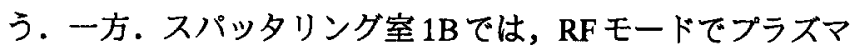
を発生することかでき，絶縁体や半導体原料の気化，クラス タ一生成が可能であることが特徽である．但し現時点では， 上記のような高い $P_{A r}$ の下で異常放電を発生させることなく高 い電力を印加してRFプラズマを維持することが困難ある.し たがって，Siクラスター発生用 RF投入電力を 200 W以下に固 定し, Coクラスター発生用 DC投入電力を $100 \sim 400 \mathrm{~W}$ に変 化させて両クラスターの堆積比を調節した.

先ず, スパッタリング室 $1 \mathrm{~A} に \mathrm{DC}$ 電力あるいはスパッタリ ング室1Bに RF電力を刋加して，CoあるいはSiのいずれかを スパッタ蒸発, クラスターを発生させ, 堆積室 3 の基板ホル ダーにセットしたカーボングリッド上に堆積させ，それらの 試料を透過電子顕微鏡により観測した。紙面の制約でここで は図示しないか，Coクラスター, Siクラスター双方ともにサ イズ単分散性が悪い ${ }^{22)}$.この理由は, 次のように考えられる. 先に開発された装置では ${ }^{6-10}$, ,クラスタ一成長室から排出され たクラスターは，差動排気により段階的に高真空室へと搬送 されて基板上に堆積させていた。一方この装置では，成長ダ クトから排出されたクラスターがArガスとともに基板上に衝 突するので, クラスターの基板上での移動, 基板に軟着陸し たクラスターのArガスによる飛散が生じる可能性が高い.そ のことを反映して，クラスター堆積状態はビームに対応した 点状でなく，堆積毎に不均一である.また，クラスターサイ ズ分布も広く，基板上でのクラスターの合体・凝集を示唆 する対数正規分布を示す。

\section{Co と Siクラスターの複合堆積}

$3.1 \mathrm{Co}$ と $\mathrm{Si}$ クラスターの湿合堆積と磁性 ${ }^{23)}$

スパッタリング室 $1 \mathrm{~A} と 1 \mathrm{~B}$ の間に仕切り板を㨂入して, $P_{\mathrm{Ar}}=$ $300 \mathrm{~Pa}$ とし, $1 \mathrm{~A}$ 室の DC電力 $250 \mathrm{~W}, 1 \mathrm{~B}$ 室の RF 電力 $150 \mathrm{~W} て ゙$ CoおよびSiクラスターを発生させ, 基板ホルダー上のマイク ログリッドに堆積させた. Fig.2はその試料の透過電子顕微鏡 (TEM) 像である. 極端にクラスターが凝集した領域と，小さ いクラスターがランダムに堆積した領域が観測される. TEM に取り付けられているエネルギー分散型X線(EDX) 分析によ れば,広い領域での平均化学組成は94at.\%Coであるのに対し て，クラスターが㠜集した領域Aの化学組成は $4 \mathrm{at} . \% \mathrm{Co}$ ，小 さいクラスターが堆積した領域Bの化学組成は 91 at.\%Coであ る.Coクラスターの凝集はそれ程顕著でないが，Coクラス ターの存在により $\mathrm{Si}$ クスターの凝集が一層促進されたと推 測される。 


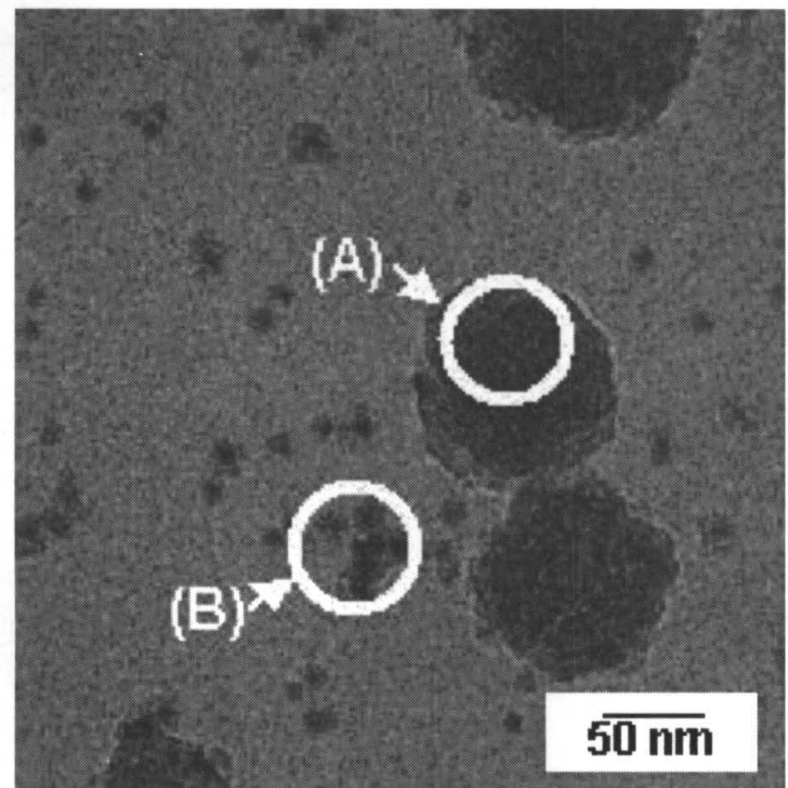

Fig.2 Bright field TEM images of Co and Si composite clusters prepared by dc and $\mathrm{rf}$ glow discharge modes with inserting the separate plate between two chambers, $1 \mathrm{~A}$ and $1 \mathrm{~B}^{23}$. (a) the TEM image for a higher cluster density region and (b) that for a lower cluster density region, respectively. The average chemical composition of this cluster assembly is 94 at.\% Co.

Fig.3は同様の条件でより多くのクラスターを堆積させた試 料 (平均化学組成 72 at.\% Co) の電子回折図形を示す. fcc 回折 リングとハローリングが重盢しており, 前者は Co クラス ター, 後者は $\mathrm{Si}$ クラスターに対応している.また, 僅かなが ら $\mathrm{NaCl}$ タイプの回折リングが検出され, $\mathrm{CoO}$ 相が存在するこ とを示唆している. スパッタリング室 $1 \mathrm{~A}$ と $1 \mathrm{~B}$ の間に仕切り 板を挿入し, 高い $P_{\mathrm{Ar}}$ の条件下で作製しているので, クラス ター核生成はスパッタリング室で生じる. そして, 成長ダク トにおいて, 成長しつつあるCoとSiクラスターが衝突する. Co-Si系平衡状態図においで ${ }^{2 \oplus,}, \mathrm{Co}$ 中には1000Kで $\mathrm{Si}$ が12 at.\%

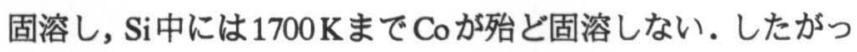
て, 高い $P_{\mathrm{As}}$ 環境下でほぼ室温に冷却された Co と $\mathrm{Si}$ のクラス ター同士は化合物相形成に至らないと推測される．但し, $\mathrm{EDX}$ 分析時のコンタミネーションのため, Coクラスターと $\mathrm{Si}$ のクラスターが重なって存在するのか, 或いは両者の界面で 合金化が生じているかを判別することができなかった.

Fig.4は, 同様の条件でより多くのクラスターを堆積させた

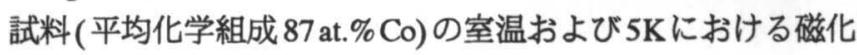
曲線を示す. 磁化は比較的飽和しやすく, 保磁力 $H_{\mathrm{C}}$ は $300 \mathrm{~K}$ で $1.6 \mathrm{kA} / \mathrm{m}, 5 \mathrm{~K} て ゙ 32 \mathrm{kA} /$ である. Si クラスターがCoクラス ターと混在しているが, Coの化学組成が高く, また飛行中に もCoクラスター同士が衝突するので，Co クラスターのネッ トワークができて多磁区構造をとり, 磁壁移動が磁化過程を 支配していると予想される. 電子回折において反強磁性 $\mathrm{CoO}$ の存在が僅かに認められたので，それによる交換磁気異方性

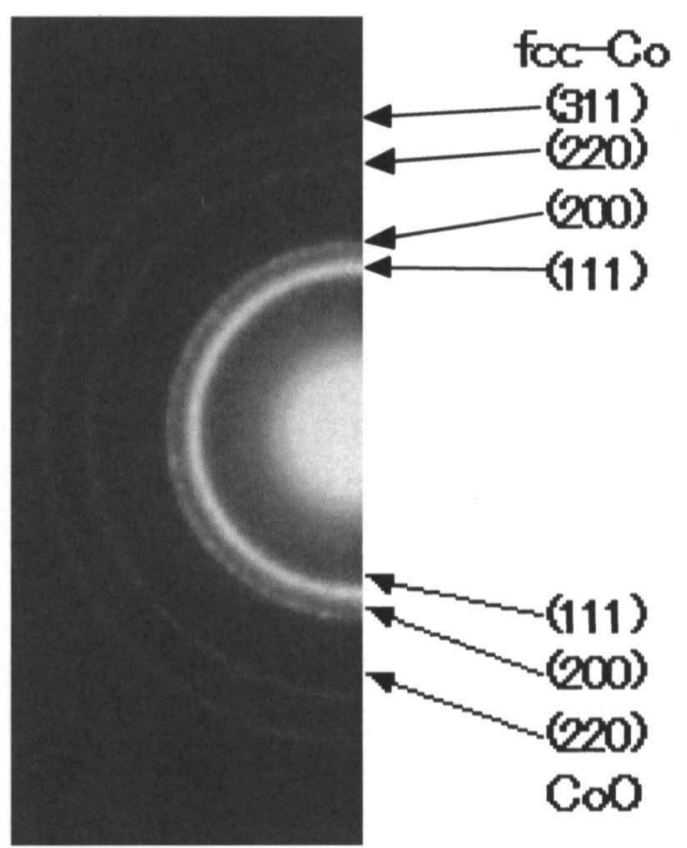

Fig.3 A selected area electron diffraction pattern of of $\mathrm{Co} / \mathrm{Si}$ composite clusters prepared by dc and rf glow discharge modes with inserting the separate plate between two chambers, $1 \mathrm{~A}$ and $1 \mathrm{~B}^{23}$. The average chemical composition of the cluster assemblies is 94 at.\% Co by EDX analyses.
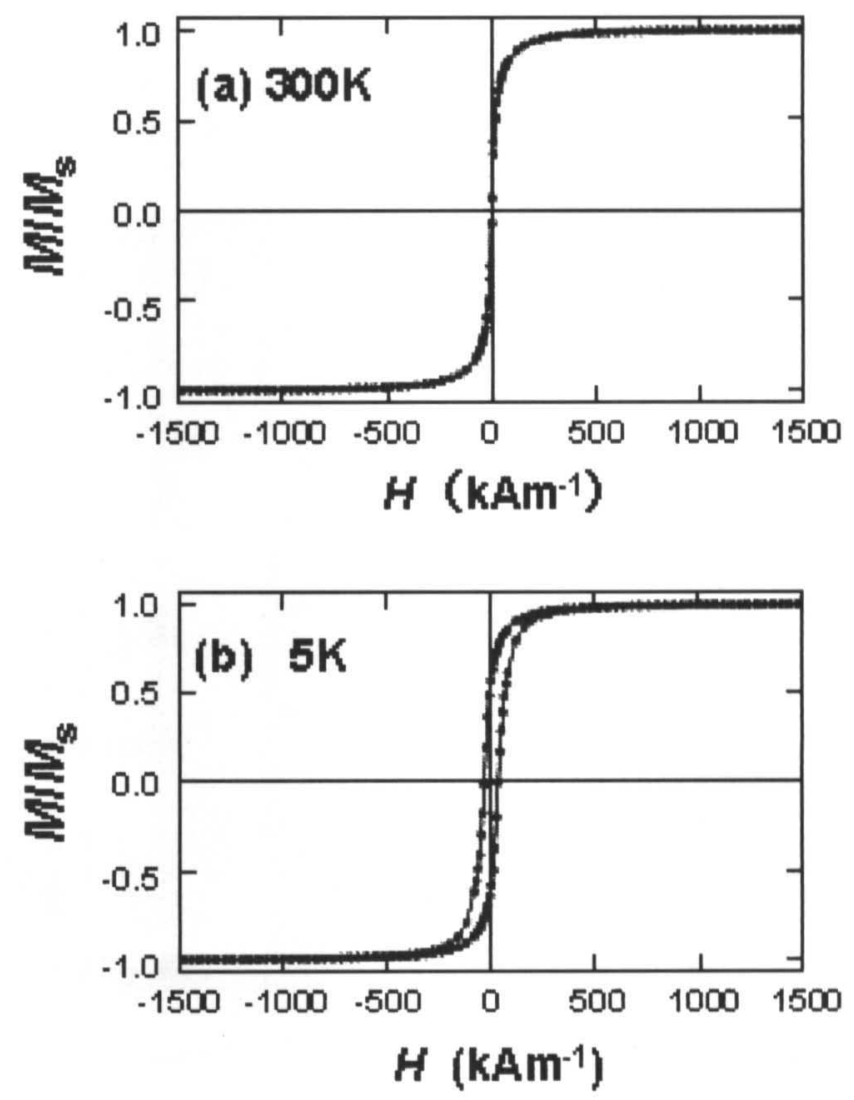

Fig.4 Magnetization curves at (a) 300 and (b) $5 \mathrm{~K}$ for $\mathrm{Co} / \mathrm{Si}$ composite cluster assemblies prepared with inserting the separate plate between two chambers, $1 \mathrm{~A}$ and $1 \mathrm{~B}^{23)}$. Its average chemical composition is 87 at.\% Co. 


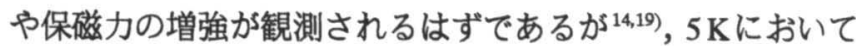
も $H_{\mathrm{C}}$ が小さく Si クラスターと共存することにより Co クラス ターの酸化が抑制されたと推測される.

$3.2 \mathrm{Co} / \mathrm{Si}$ コアシェルクラスター集合体と磁性

スパッタリング室1Aと1Bの間に仕切り板を挿入せず, $P_{\mathrm{Ar}}=$ $300 \mathrm{~Pa}$ とし, $1 \mathrm{~A}$ 室の DC電力 $250 \mathrm{~W}, 1 \mathrm{~B}$ 室の RF電力 $150 \mathrm{~W}$ と して, CoおよびSi クラスターを発生させ, 基板ホルダー上の マイクログリッドに堆積させた. Fig.5はその試料 (平均化学 組成 22 at.\% Co)の TEM像である. 暗いコントラストのコア領 域を明るいコントラストのシェル領域が取り囲む組織が観測 される. マイクロビーム EDX 分析による局所的化学組成は, コア領域 Aで 45 at.\%Co，シェル領域 B で 18at.\%Co となる. Fig.6は同様の条件でより多くのクラスターを堆積させた試料 (平均化学組成 22 at.\% Co) の電子回折図形を示す. Fig.3 と類似 して, 線幅の広いfcc回折リングとハローリングが重盢してお り, 前者は Coコア領域, 後者はSiシェル領域に対応している が, $\mathrm{CoO}$ 相に対応する回折リングは検出されない. スパッ夕 リング室 $1 \mathrm{~A} と 1 \mathrm{~B}$ の間に仕切り板が無く, Coおよび $\mathrm{Si}$ クラス ターの核生成は核生成の段階から衝突をはじめ, 成長ダク卜 に搬送され成長していく.Co-Si合金系には, 生成エネルギー の大きい金属間化合物が存在するので，小さな Co と Si のク ラスターが衝突すると, 室温でも瞬間的な合金化が生じると 予想された ${ }^{25)}$. しかし実際には, $\mathrm{Co} / \mathrm{Si}$ コアシェルクラスター が形成された．Co と Si の表面エネルギーを比較すると Si の 方がCoに比べて1桁小さく ${ }^{29,} \mathrm{Co}$ と Si のクラスター核が衝 突したとき, $\mathrm{Si}$ クラスターがCoクラスターの表面に付着して

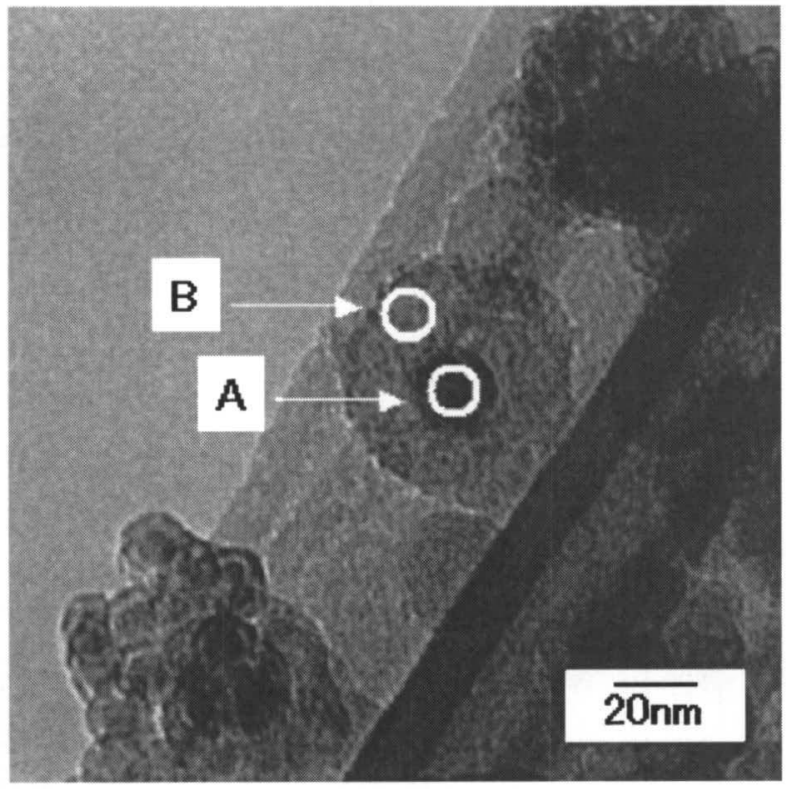

Fig.5 Bright field TEM image and energy-dispersive X-ray analyses of $\mathrm{Co} / \mathrm{Si}$ composite clusters prepared by dc and $\mathrm{rf}$ glow discharge modes without inserting the separate plate between two chambers, $1 \mathrm{~A}$ and $1 \mathrm{~B}^{23}$. The region marked by $\mathrm{A}$ is about 45 at.\% Co and the one marked by $\mathrm{B}$ about 18 at.\% $\mathrm{Co}$, whereas the average chemical composition of these cluster assemblies is about 22 at.\% Co.
安定化が図られ,Co-Si金属間化合物が形成されなかったと推 測される. 但し, 先のCoと Si クラスターが混在する場合と同 様, EDX分析により局所的な合金化が生じているか否かにつ いては判別できなかった.

Fig.7は, 同様の条件でより多くのクラスターを堆積させた

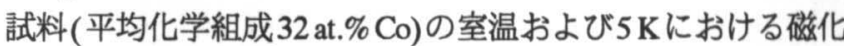
曲線を示す.いずれの温度においても磁化は飽和しており， $H_{\mathrm{C}}$ は $300 \mathrm{~K} て ゙ 2.4 \mathrm{kA} / \mathrm{m}, 5 \mathrm{~K}$ で $40 \mathrm{kA} /$ である.しかし, Fig.4と 比較すると, 飽和し難く, $H_{\mathrm{C}}$ も少し大きい. Coクラスターか $\mathrm{Si}$ クラスターにより取り囲まれたコアシェル構造になってお り，反強磁性 $\mathrm{CoO}$ の影響は見られない ${ }^{14,19}$. そのため, Coク ラスター間の磁気的相互作用が弱められ, Coクラスターが単 磁区粒子となり $300 \mathrm{~K} て ゙$ 超常磁性を示し，5Kにおいて単磁区 粒子の回転による磁気異方性が強調されたと推測される。

\section{4 要約}

クラスター集合体の機能性を向上させるため2源プラスマ・ ガス凝縮クラスター生成・堆積装置を試作した. 金属クラス ターと半導体・絶縁体クラスターの複合化を目指し，スパッ タリング用プラズマの一つはDCモード，もう一つはRFモー ドで作動させることができ，仕切り板により2つのプラズマ で発生した気化原子や生成クラスターの衝突時期(場所)を変 化させることができる.この装置を用いて，Coクラスターと $\mathrm{Si}$ クラスターを発生・堆積させた試料について, 透過電子顕

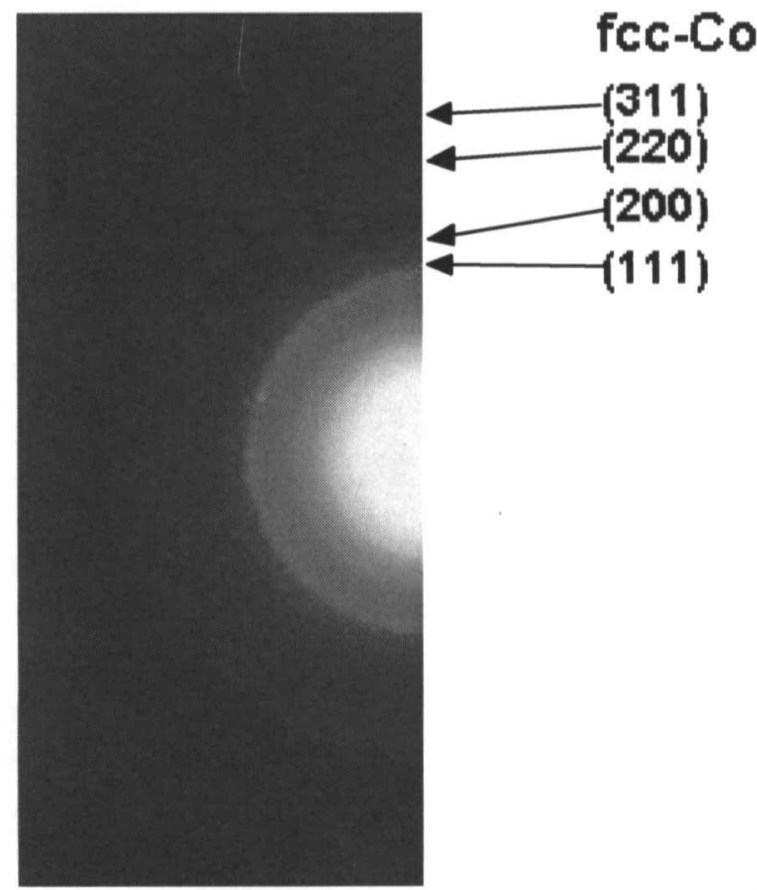

Fig.6 A selected area electron diffraction pattern of $\mathrm{Co} / \mathrm{Si}$ composite clusters deposited on a carbon micro-grid by $\mathrm{dc}$ and if glow discharge modes without inserting the separate plate between two chambers, $1 \mathrm{~A}$ and $1 \mathrm{~B}^{23}$. The average chemical composition of the cluster assemblies is 37 at.\% Co by EDX analyses. 

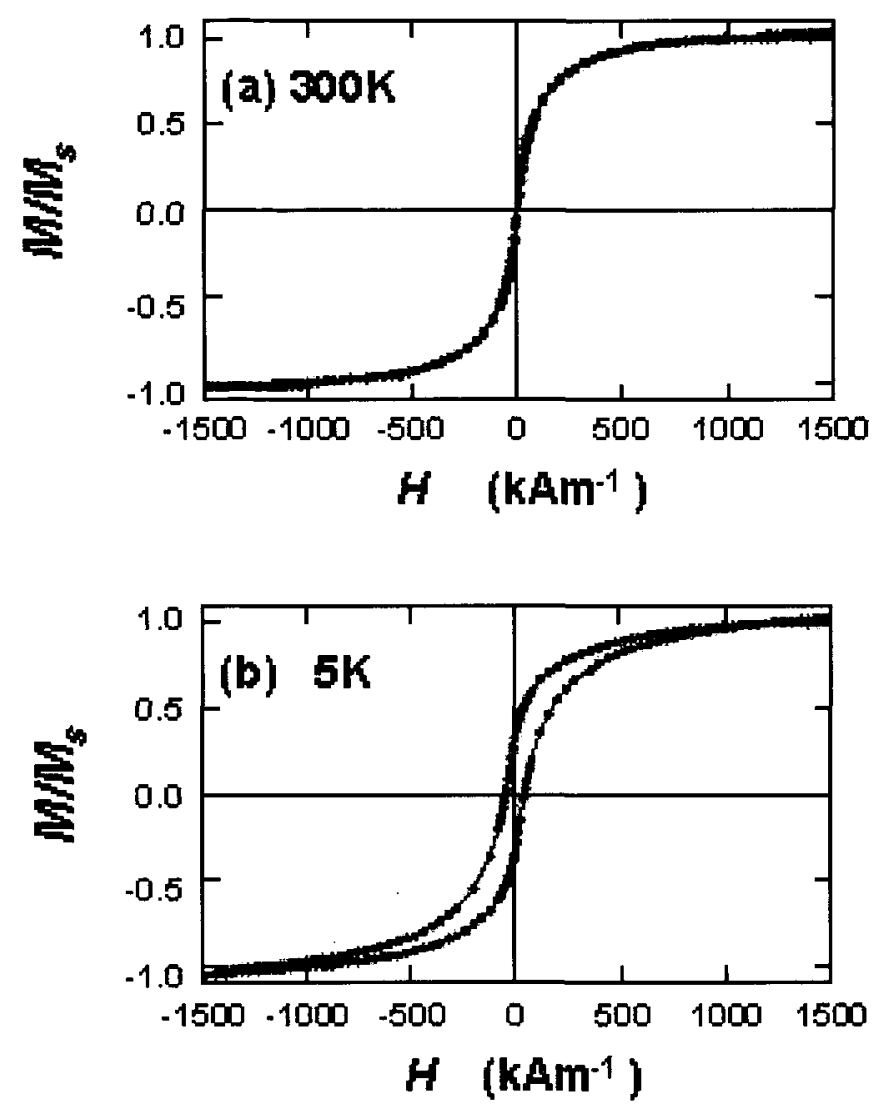

Fig.7 Magnetization curves at (a) 300 and (b) $5 \mathrm{~K}$ for $\mathrm{Co} / \mathrm{Si}$ composite cluster assemblies prepared without inserting the separate plate between two chambers, $1 \mathrm{~A}$ and $1 \mathrm{~B}$. Its average chemical composition is 32 at. $\% \mathrm{Co}^{23)}$.

微鏡観察, 電子回折ならびにSQUID磁力計による磁化測定を 行った. 仕切り板を㨂入して作製した試料は，Coクラスター とSiクラスターの混在状態となる.一方, 仕切り板を挿入せ ずに作製した試料は CoクラスターがSi クラスターで取り囲 まれたコアシェル構造を示す.いずれの試料も300 Kで軟磁性

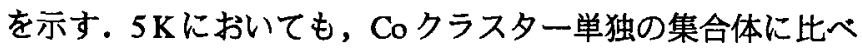
て保磁力は小さく，反強磁性 $\mathrm{CoO}$ の形成力゙抑制されている。 特にコアシェルクラスターの方が表面酸化の抑制効果がより 顕著であり，クラスターを部品として集合化させるマテリア ルプロセスに応用できると期待される。

\section{謝辞}

本研究は，科学技術振興事業団・戦略的基礎研究「極限環 境状態における現象」, 愛知・名古屋地区知的クラスタ一創成 事業「ナノテクを利用した環境にやさしいものづくり構想」 ならびに名古屋工業大学 21 世紀 COE プログラム「環境調和 セラミックス科学の世界拠点」の一睘として実施したもので ある.これまで，こ指導，こ支援戴いた関係各位に深謝する。 また,東北大学金属材料研究所の若生公郎技官の技術的支援, 本学卒業生の角田航介君の実験的支援に感謝する.

\section{文献}

1) A.S.Edelstein and R.C.Cammarata ed.: "Nanomaterials Synthesis, Properties and Applications", Institute of Physics, (1996).

2) R.Uyeda ed.: "Ultrafine Particles", AGNE Technical Center, (1984) (in Japanese).

3) The Chemical Society of Japan ed.: "Ultrafine Particles-Science and Applications", Japan Scientific Societies Press, (1985) (in Japanese).

4) H.Murakami, M.Hirakawa, Y.Ohtsuka, H.Yamakawa, N.Imazeki, S.Hayashi, T.Suzuki, M.Oda and C.Hayashi: "Spinon Films for Ultra-Large Scale Integrated Metallization", J. Vac. Sci. Tech., B17(1999)2321-2324.

5) P.Mélinon, V.Paillard, V.Dupuis, A.Perez, P.Jensen, A.Hoareau, J.P.Perez, J.Tuaillon, M.Broyer, J.L.Vialle, M.Pellarin, B.Bauguenard and J.Lerme: "From Free Clusters to ClusterAssembled Materials", Int. J. Mod. Phys., B9(1995)339-397.

6) H.Haberland, M.Karrais, M.Mall and Y.Thurner: "Thin Films from Energetic Cluster Impact: A Feasibility Study", J. Vac. Sci. Tech., A10(1992)3266-3271.

7) S.Yamamuro, K.Sumiyama, M.Sakurai and K.Suzuki: "Cr Cluster Deposition by Plasma-Gas-Condensation Method", Supramolecular Sci., 5(1998)239-245.

8) S.Yamamuro, K.Sumiyama and K.Suzuki: "Monodispersed $\mathrm{Cr}$ Cluster Formation by Plasma-Gas-Condensation", J. Appl. Phys., 85(1999)483-489

9) T.Hihara and K.Sumiyama: "Formation and Size Control of a Ni Ccluster by Plasma Gas Condensation", J. Appl. Phys., 84 (1998)5270-5276.

10) T.Hihara and K.Sumiyama: "Time-of-Flight High-Mass Spectrometer Observation of Large Size Nb Clusters toward Assembling of Size Controlled Clusters", J. Vac. Sci. Tech., B17(1999)1923-1829.

11) P.Jensen: "Growth of Nanostructures by Cluster Deposition: Experiments and Simple Models", Rev. Mod. Phys., 71(1999) 1695-1735.

12) S.Yamamuro, K.Sumiyama, T.Hihara and K.Suzuki: "Geometrical and Eelectrical Percolation in Nanometer-Sized Co-Cluster Assemblies", J. Phys. Cond. Mat., 11(1999)3247-3257.

13) S.Yamamuro, K.Sumiyama, T.J.Konno and K.Suzuki: "Structural and Magnetic Evolution in Self-Assembling Process of Nanometer-Sized Co Clusters", Mat. Trans. JIM, 40(1999) 1450-1455.

14) S.Yamamuro, K.Sumiyama, T.Kamiyama and K.Suzuki: "Morphological and Magnetic Characteristics of Monodispersed Co-Cluster Assemblies", J. Appl. Phys., 86(1999)5726-5732.

15) M.Oda: "Formation of Composite and Isolated Ultrafine Particles by Gas Evaporation Method", C.Hayashi ed: "Ultrafine ParticlesCreation Science and Technology", Mita Publishing Society, 
(1988)115-132 (in Japanese).

16) D.L.Peng, H.Yamada, T.Hihara, T.Uchida and K.Sumiyama: "Dense Fe Films Prepared by Energetic Cluster Deposition", submitted to Appl. Phys. Lett., (2004).

17) D.L.Peng, T.J.Konno, K.Wakoh, T.Hihara and K.Sumiyama: "Co Cluster Coalescence Behavior Observed by Electrical Conduction and Transmission Electron Microscpopy", Appl. Phys. Lett., 78(2001)1535-1527.

18) D.L.Peng, K.Sumiyama, T.J.Konno T.Hihara and S.Yamamuro: "Characteristic Transport Properties of CoO-Coated Mmonodispersive Co Cluster Assemblies", Phys. Rev., B60 (1999) 2093-2100.

19) D.L.Peng, K.Sumiyama, S.Yamamuro, T.Hihara and T.J.Konno: "Preparation and Magnetic Properties of Oxide-Coated Monodispersive Co Cluster Assembly", Phys. Stat. Sol. (a), 172 (1999)209-216.

20) D.L.Peng, K.Sumiyama, T.Hihara, S.Yamamuro and T.J.Konno: "Magnetic Properties of Monodispersed $\mathrm{Co} / \mathrm{CoO}$ Clusters", Phys. Rev., B61 (2000)3103-3109.
21) D.L.Peng, T.Hihara and K.Sumiyama: "Formation and Magnetic Properties of Fe-Pt Alloy Clusters by Plasma-Gas Condensation", Appl. Phys. Lett., 83(2003)350-352.

22) R.Katoh, T.Hihara, D.L.Peng and K.Sumiyama: "Composite Deposition of Co and Si Clusters by RF/DC Plasma-GasCondensation", Appl. Phys. Lett., 82(2003)2688-2690.

23) R.Katoh, K.Sumiyama, T.Hihara and D.L.Peng: "Composite state control and magnetic properties of cobalt and silicon cluster assemblies prepared with double plasma discharge sources", Mat. Trans. JIM, (2004) in press.

24) T.B.Massalski, J.L.Murray, L.H.Bennett, H.Baker and L.Kacprzak: "Binary Alloy Phase Diagrams", Metals Park, Ohio, American Society of Metals, (1986)801.

25) H.Mori, M.Komatsu, K.Takeda and H.Fujita: "Spontaneous Alloying of Copper into Gold Atom Clusters", Phil. Mag. Lett., 63(1991)173-178.

26) F.R.de Boer, R.Boom, W.C.Mattens and A.R.Miedema: "Cohesion in Metals-Transition Metal Alloys", North-Holland, Amsterdam, (1988)662. 